\title{
MANAJEMEN PENDIDIKAN ISLAM BERBASIS LIFE SKILL DI PONDOK PESANTREN TAHFIDZ AS-SYAHIDUL KABIR BLUMBUNGAN PAMEKASAN
}

\author{
Ahmad, Moh. Soheh \& Sitti Mukamilah \\ Universitas Islam Madura \\ Email: ahmadasir@gmail.com
}

\begin{abstract}
Abstrak:
Pondok pesantren dituntut untuk lebih meningkatkan kualitasnya dibidang keagamaan, intelektual, dan life skill yang mumpuni, sehinggga eksistensi pondok pesantren tetap kokoh. Hal ini disebabkan tidak semua lulusan pondok pesantren akan menjadi Ulama atau Kiai, dan memilih lapangan pekerjaan dibidang agama, maka keahlian-keahlian lif skill perlu diberikan kepada santri sebelum terjun ketengah-tengah masyarakat. Tujuan dari penelitian ini untuk mengetahui implementasi pendidikan islam berbasis life skill di pondok pesantren As-Syahidul Kabir Sumber Batu Blumbungan. Penelitian ini merupakan penelitian deskriptif kualitatif dengan tekhnik pengumpulan data yaitu survey lapangan, observasi, dan wawancara,. Sistem pendidikan Islam berbasis lifeskill di Pondok Pesantren AsSyahidul Kabir diimplementasikan dalam porsi tersendiri, yaitu tidak tersusun dalam satuan kurikulum pada jenjang pendidikan yang diterapkan di pondok pesantren. Pendidikan Islam berbasis lifeskill diterapkan dalam bentuk kegiatankegiatan ekstrakurikuler yang tidak semua santri diwajibkan untuk mengikutinya, namun tergantung pada kesadaran dari masing-masing santri.
\end{abstract}

Kata Kunci: Manajemen Pendidikan Islam, Life Skill

\begin{abstract}
:
Pesantren are demanded to further improve their quality, the religious, intellectual fields, furthemore; life skills's qualified, so that the existence of boarding schools remains strong. This is because not all graduates of Islamic boarding schools will become piosman that are part of life skills need to be given to students before plunging into the midst of the actual community. The purpose of this research is to find out the implementation of life skill-based Islamic education in As-Syahidul Kabir's Islamic Boarding School. This is a qualitative research desing that analyzed by using descriptive, and the data collection's techniques of this research are survey, observations, and interviews. In the As-Syahidul Kabir's boarding school, , life skillbased Islamic education is implemented in a separate portion, which is not arranged in curriculum units at the level of education applied in boarding schools. Life skillbased Islamic education is implemented in the form of extracurricular activities where not all students are required to participate, but it depends on their's awareness.
\end{abstract}

Keywords : The Management of Islamic Education, Life Skill. 


\section{Pendahuluan}

Pesantren merupakan sebuah lembaga pendidikan yang cukup tua di Indonesia. Pesantren didefinisikan sebagai lembaga pendidikan tradisional Islam untuk mempelajari, memahami, mendalami, menghayati, dan mengamalkan ajaran Islam dengan menekankan pentingnya moral keagamaan sebagai pedoman perilaku sehari-hari. Pesantren merupakan institusi yang pada hakikatnya berjiwa sangat kontemporer, bahkan telah menggunakan sistem pendidikan yang hingga saat ini masih diramu ketepatannya oleh para pendidik modern dengan sangat sempurna.

Secara umum pesantren dapat dikategorikan, menjadi : 1) Pesantren Salafiyah yaitu pesantren yang masih tetap mempertahankan sistem pendidikan khas pesantren, baik kurikulum maupun metode pendidikannya. Buku ajar yang digunakan berupa ilmu-ilmu agama Islam, dengan menggunakan kitab-kitab klasik berbahasa Arab yang sesuai dengan tingkat kemampuan masing-masing santri. Sering disebut sebagai pesantren tradisonal dan santrinya dinamakan santri Salafiyah. Pesantren Salafiyah 2) Pesantren Kholafiyah yaitu pesantren yang mengadopsi sistem madrasah atau sekolah, dengan kurikulum disesuaikan dengan kurikulum pemerintah baik dari departemen Agama maupun Departemen Pendidikan Nasional. Pesantrren kholafiyah disebut juga pesantren modern.

Di tengah pesatnya perkembangan teknologi saat ini, yaitu perkembangan teknologi revolusi industri 4.0, pesantren tetap kokoh dengan semangat tetap menjaga tradisi kepesantrenan yang mengagumkan. Pada hakikatnya, sistem pendidikan pondok pesantren adalah totalitas interaksi seluruh komponen yang bekerjasama secara terpadu dan saling melengkapi antara yang satu dengan yang lainnya. Hakikat pendidikan pondok pesantren terletak pada isi (content) dan jiwanya, bukan pada "kulit luarnya". Isi pondok pesantren adalah pendidikan "ruhaniyah" yang telah berhasil melahirkan kader-kader dan pemimpin umat di berbagai bidang kehidupan. ${ }^{1}$

Perkembangan pesantren sangat ditentukan oleh faktor manajemen. Pesantren yang masih akan berkembang jika dikelola secara profesional maka akan maju, dengan pengelolaan yang sama, pesantren yang sudah berkembang akan semakin maju. Sebaliknya, pesantren yang lebih maju akan mengalami kemunduran manakala manajemennya tidak terurus dengan baik. Sementara itu, pesantren yang yang masih belum berkembang akan terhambat dalam menghadapi tantangan multidimensi jika manajemen pengelolaan tidak diterapkan dengan baik. Tantangan itu bisa berupa tuntutan-tuntutan keterbukaan (inklusivisme), pengembangan metodologi, kemampuan manajerial, kolektivitas, demokratisasi, kebersamaan, egalitarianisme, dan lain-lain. Semua tantangan itu terakumulasi menjadi satu tantangan besar yang memaksa pesantren untuk memberikan perubahan manajemen khususnya dalam bidang pendidikan.

Seiring berkembangnya ilmu pengetahuan dan teknologi (IPTEK), pondok pesantren dituntut untuk lebih meningkatkan kualitasnya, baik dibidang keagamaan, intelektual. maupun life skill yang mumpuni, sehinggga eksistensi

\footnotetext{
${ }_{1}^{1}$ Mu'awanah, Manajemen Pesantren Mahasiswa:Studi Ma'had UIN Malang (Kediri: STAIN Kediri Press, 2009), 27.
} 
pondok pesantren tetap kokoh. ${ }^{2}$ Selain itu pondok pesantren juga dituntut untuk menyajikan pendidikan yang sesuai dengan perkembangan zaman. Sebab pendidikan merupakan penunjang yang sangat mendasar bagi perubahan dan kemajuan masyarakat. ${ }^{3}$ hal ini disebabkan tidak semua lulusan pondok pesantren akan menjadi ulama atau kiai, dan memilih lapangan pekerjaan dibidang agama, maka keahlian-keahlian lain seperti pendidikan keahlian dan keterampilan yang merupakan bagian dari life skill perlu diberiakan kepada santri sebelum terjun ketengah-tengah masyarakat sebenarnya.

Fakta dilapangan, masih ada problem banyaknya alumni atau lulusan pondok pesantren akan minimnya pengetahuan tentang kebutuhan dunia kerja menyebabkan semakin menambahnya banyaknya pengangguran, disamping penyerapan lulusan pendidikan formal dan nonformal juga masih rendah. Upaya pendekatan dunia pendidikan dan dunia kerja dengan kata lain pendidikan berbasis life skill harus dimulai sejak awal, sehingga pendidikan pondok pesantren mampu menghasilkan generasi muslim yang siap di segala bidang termasuk tenaga yang terampil atau mampu berusaha mandiri dan siap kerja.

Konsep manajemen dalam pendidikan digunakan sebagai pendekatan dalam pengelolaan mutu pendidikan. Peran pendidikan pada hakekatnya ditafsirkan sebagai perubahan sosial dan pusat peradaban. ${ }^{4}$ Heyneman dalam Supriadi mengemukakan bahwa kemajuan sebuah bangsa dan perubahan sosial sangat ditentukan oleh pelaksana mutu pendidikan. Pada konteks tersebut pendidikan menjadi tempat yang strategies dan untuk mengantarkan cita-cita yang dimaksud, maka dibutuhkan sistem manajemen dan strategi pendidikan Islam khususnya di lingkungan pesantren, sehingga dapat memberikan kontribusi yang siginificant dalam pengembangan dan manajemen pendidikan Islam secara lebih baik. Keunggulan SDM yang ingin dicapai pondok pesantren adalah terwujudnya generasi muda yang berkualitas tidak hanya pada aspek kognitif, tetapi juga pada aspek afektif dan psikomotorik. Namun, memandang tantangan-tantangan yang dihadapi bangsa dan upaya dalam penguasaan sains-teknologi untuk turut memelihara momentum pembangunan, muncul pemikiran dan gagasan untuk mengembangkan pondok pesantren sekaligus sebagai wahana untuk menanamkan apresiasi, dan bahkan bibit-bibit keahlian dalam bidang keterampilan berbasis life skill. Hal tersebut merupakan salah satu solusi yang menjadi tolak ukur dalam pengembangan pondok pesantren tahfiz as-syahidul kabir Blumbungan Pamekasan.

\section{Metode Penelitian}

Penelitian ini menggunakan pendekatan deskriptif kualitatif untuk memberikan informasi, pemahaman serta gambaran mengenai isi dan kualitas isi yang terjadi sasaran atau objek penelitian serta menggambarkan manajemen pondok pesantren berbasis life skill di Pondok pesantren As- Syahidul Kabir desa Blumbungan Kecamatan Larangan Kabupaten Pamekasan. Peneliti dalam penelitian

\footnotetext{
2 Zamakhsyari Dhofier, Tradisi Pesantren: Studi Tentang Pandangan Hidup Kyai, (Jakarta: LP3ES, 1985) hal. 11.

${ }^{3}$ Hasan Langgulung, Kreatifitas Pendidikan Islam (Jakarta: Pustaka Al Husna, 1991) hal. 56.

4 Steenberk.,Karel A., Pesantren.,Madrasah, Sekolah: Pendidikan Islam dalam Kurun Modern (Jakarta:LP3ES, 1994), 08.
} 
ini bertindak sebagai instrument atau pengumpul data yang diperoleh dengan survey lapangan, wawancara dan observasi sehingga dapat mengetahui dan memahami gambaran yang utuh tentang objek penelitian.

\section{Pembahasan dan Hasil Penelitian}

Life skill (kecakapan hidup) adalah kemampuan, kesanggupan, dan keterampilan yang diperlukan seseorang untuk menjalankan kehidupan dengan nikmat dan bahagia. kecakapan tersebut mencakup segala aspek sikap prilaku manusia sebagai bekal dalam kehidupannya ${ }^{5}$. Pendidikan Islam berbasis life skill merupakan pendidikan yang memberi bekal dasar dan latihan yang dilakukan secara benar kepada peserta didik tentang nilai-nilai kehidupan yang dibutuhkan dan berguna bagi pekembagan kehidupan ${ }^{6}$. Dengan demikian pendidikan islam berbasis life skill harus dapat merefleksikan nilai-nilai keagamaan dan kehidupan nyata dalam proses pengajaran agar peserta didik memperoleh kecakapan hidup tersebut sehinggga siap untuk hidup di tengah-tengah masyarakat ${ }^{7}$.Implemetasi pendidikan islam berbasis life skill di pondok pesantren erat sekali hubungannya dengan pengalaman yang diperlukan santri dalam menguasai materi pelajaran di pondok pesantren.

Pondok pesantren As-Syahidul Kabir Sumber Batu Blumbungan, yang merupakan pondok terbesar di blumbungan dengan jumlah santri kurang lebih 350 santri, mampu mencari dan mengembangkan bentuk pengalaman belajar santri, yaitu hal tersebut tidak terlepas dari strategi pembelajaran yang digunakan oleh pondok pesantren itu sendiri, baik dari pendekatan ataupuun metodologinya. Pondok pesantren As-Syahidul Kabir Sumber Batu Blumbungan sudah mampu mengembangkan pembelajaran yang lebih variatif dan eksploratif dengan berbagai metode dan pendekatan, diantaranya dengan menerapkan dan mengimplementasikan pendidikan islam berbasis life skill di pondok pesantren yang dapat dikemas dengan berbagai macam bentuk kegiatan yang sudah ada, seperti kursus, pelatihan, dan penyediaan wahana atau wadah bagi santri untuk mengaplikasikan keterampilan dan keahlian yang sudah diajarkan kepada santri tersebut.

Berdasarkan data yang telah diperoleh oleh peneliti, baik dari hasil survey lapang, observasi, wawancara, peneliti menemukan bahwa prinsip implementasi komponen pendidikan islam berbasis life skill sudah ada di pondok pesantren AsSyahidul Kabir Sumber Batu Blumbungan, hal ini ditandai dengan sudah adanya pendidikan-pendidikan yang berorientasi pada keterampilan dan keahlian santri, hanya saja implementasi pendidikan islam berbasis life skill yang ada di pondok pesantren As-Syahidul Kabir Sumber Batu Blumbungan diposisikan secara terpisah, dalam artian, tidak tersusun dalam bentuk satuan kurikulum pada jenjang pendidikan yang sudah ada (pendidikan formal), akan tetapi implementasi

\footnotetext{
5 Muchlas Samani, Kecakapan Hidup Melalui Pendekatan Pendidikan Berbasis Luas (Surabaya: Swa Bina Qualita Indonesia, 2016), 69

6 Zainal Abidin, Implementasi pendidikan life skill (Darussalam jurnal pendidikan, komunikasi dan pemikiran hukum islam. vol. IV. No. 1, 2014)

${ }^{7}$ M. Bahri Ghazali, Pesantren Berwawasan Lingkungan, (Jakarta: Prasasti, 2003) 37
} 
pendidikan islam berbasis life skill diposisikan pada bagian tersendiri dengan pengelolaan yang tersendiri pula, yaitu dengan dibentuknya lembaga keterampilan, keorganisasian, kegiatan kursus, dan pelatihan.

Dengan demikian tidak ada keharusan bagi setiap santri untuk mengikuti semua bentuk kegiatan life skill yang ada di pondok pesantren. Hal ini dengan alasan karena kegiatan-kegiatan life skill di pondok pesantren As-Syahidul Kabir Sumber Batu Blumbungan memang bukan hal yang diwajibkan menurut kurikulum pendidikan pondok pesantren. Pendidkan islam berbasis life skill dikemas dalam bentuk kegiatan-kegiatan ekstrakurikuler yang hanya diikuti oleh santri yang mau dan menginginkannya. Hal ini dikarenakan kurang adanya kesadaran dari diri pribadi santri akan pentingnya pendidikan islam yang berbasis life skill sebagai modal sanntri ataupun alumni dari pondok pesantren untuk menjadi manusia mandiri dalam menghadapi kehidupan di masyarakat yang semakin modern, dan persaingan dunia kerja yang semakin kompetitif. Adapun salah satu bentuk cara implementasi pendidikan islam berbasis life skill di pondok pesantren adalah sebagai berikut:

a) Implementasi Pendidikan Islam Berbasis Life Skill Dalam Bentuk Personal Skill

Salah satu bentuk dari implementasi personal skill dalam pondok pesantren As-Syahidul Kabir Sumber Batu Blumbungan adalah dengan diwajibkannya santri untuk selalu mengikuti sholat lima waktu dengan berjamaah, dan mengaji alqur'an. Hal ini dilakukan agar santri mampu mempraktekkan materi fiqih yang diajarkan disekolah, juga akan lebih mengetahui akan pentingnya disiplin waktu. Bentuk lain dari implementasi personal skill adalah dengan adanya program amtsilati (program cepat baca kitab kuning) dengan membaca kitab sekaligus menjelaskan maksudnya, hal ini dilakukan dalam rangka membentuk kesadaran pada diri santri bahwa mereka memiliki potensi.

b) Implementasi Pendidikan Islam Berbasis Life Skill Dalam Bentuk Thinking Skill Implementasi thinking skill dilakukan dengan memberikan pengalaman membahas kitab yang sudah dipelajari. Hal ini dilakukan agar santri membiasakan berfikir. Dari sinilah kecakapan berfikir rasional akan tumbuh pada diri santri.

c) Implementasi Pendidikan Islam Berbasis Life Skill Dalam Bentuk Social Skill Implementasi kecakapan sosial dilakukan dengan didirikannya organisasiorganisasi santri sebagai wahana pembelajaran bagi santri dalam penanaman jiwa kepemimpinan, yaitu kecakapan bekerjasama juga akan terekontruksi.

d) Implementasi Pendidikan Islam Berbasis Life Skill Dalam Bentuk Academic Skill

Salah satu bentuk dari implementasi academis skill adalah dengan adanya kegiatan pengajian kitab kuning baik dalam hal pemahaman isi maupun keterkaitannya dengan masalah-masalah waqiiyah (masalah riil yang terjadi dalam kehidupan sehari-hari). dari kegiatan inilah kecakapan akademik bisa berkembang.

e) Implementasi Pendidikan Islam Berbasis Life Skill Dalam Bentuk Vocational Skill

Sebagai implementasi vocational skill di pondok pesantren selain diadakannya kegiatan kursus juga telah didirikan beberapa lembaga keterampilan seperti 
keterampilan pendidikan komputer, seni baca alqur'an dan kegiatan-kegiatan lain yang dapat menunjang santri menjadi muslim yang kreatif dan mandiri.

Dengan adanya implementasi pendidikan islam berbasis life skill di Pondok Pesantren As-Syahidul Kabir, maka para santri dan lulusan mempunyai kecakapan yang lebih komprehensif, sehingga akan bermanfaat bagi pegembangan diri para santri ketika terjun dan mengabdi di lingkungan masyarakat. Para santri dan lulusan tidak hanya dapat mengembangkan kemampuan dalam bidang tahfidz, dan akademik, namun dapat mengeksplor kemampuan yang dimiliki para santri dalam bentuk personal skill, thinking skill, social skill, dan kemampuan extrakurikuler lainnya, sehingga para santri dapat mengembangkan kemampuan tersebut secara mandiri dan dapat mendukung pendidikannya di masa yang akan datang.

\section{Penutup}

Berdasarkan hasil pembahasan dari penelitian ini, maka peneliti dapat menyimpulkan bahwa implementasi pendidikan islam berbasis life skill sudah ada di pondok pesantren As-Syahidul Kabir Sumber Batu Blumbungan. Sistem pendidikan Islam di pondok pesantren As-Syahidul Kabir Sumber Batu Blumbungan, berbasis life skill diimplementasikan dalam porsi tersendiri, dalam hal ini, tidak tersusun dalam satuan kurikulum pada jenjang pendidikan yang ada di pondok pesantren. Pendidikan islam berbasis life skill diterapkan dalam bentuk kegiatan-kegiatan ekstrakurikuler dimana tidak semua santri diwajibkan untuk mengikutinya. Implementasi pendidikan islam berbasis life skill memberikan kontribusi yang significant terhadap pengembangan kecakapan dan kemampuan para santri dalam mengembangkan skill yang dimilikinya, sehingga para santri mendapatkan berbagai macam keahlian dibidang agama, umum, wirausaha, dan pengembangan personal dan sosial skill para santri yang nantinya dapat diterapkan di lingkungan pendidikan dan masyarakat secara mandiri.

\section{Daftar Pustaka}

Abidin, Zainal. Implementasi Pendidikan Life Skill, Jurnal Pendidikan, Komunikasi, dan Pemikiran Hukum Islam, volume 6, No. 1; September 2014.

Arikunto, Suharsimi. Prosedur Penelitian. (Jakarta: PT RINEKA CIPTA. 2013)

Hasan Langgulung, Kreatifitas Pendidikan Islam (Jakarta: Pustaka Al Husna, 1991)

Muchlas Samani, Kecakapan Hidup Melalui Pendekatan Pendidikan Berbasis Luas (Surabaya: Swa Bina Qualita Indonesia, 2016)

M. Bahri Ghazali, Pesantren Berwawasan Lingkungan, (Jakarta: Prasasti, 2003)

Mu'awanah, Manajemen Pesantren Mahasiswa:Studi Ma'had UIN Malang (Kediri: STAIN Kediri Press, 2009)

Steenberk.,Karel A., Pesantren.,Madrasah, Sekolah: Pendidikan Islam dalam Kurun Modern (Jakarta:LP3ES, 1994)

Supriadi, Mengangkat Citra dan Martabat Guru, (Jakarta:Adicita Karya Nusantara, 2012).

Zamakhsyari Dhofier, Tradisi Pesantren: Studi Tentang Pandangan Hidup Kyai, (Jakarta: LP3ES, 1985) 